\title{
OPTIMALISASI FUNGSI RUANG TERBUKA HIJAU DENGAN MELIHAT POLA SEBARAN PENGUNJUNG STUDI KASUS: TAMAN TABEBUYA, JAGAKARSA
}

\author{
Ari Widyati Purwantiasning ${ }^{1}$ \\ Jurusan Arsitektur, Universitas Muhammadiyah Jakarta \\ e-mail: *1arwityas@yahoo.com
}

\begin{abstract}
Abstrak_Penyediaan ruang terbuka publik di dalam perkotaan terutama di kota metropolitan seperti Jakarta menjadi sebuah isu yang tidak pernah terselesaikan dengan baik. Terbatasnya lahan perkotaan dan juga area bebas yang seharusnya disediakan untuk ruang terbuka publik sangat sulit didapatkan. Saat ini sebagai salah satu solusinya, pemerintah daerah memiliki kemauan dalam memikirkan solusi masalah ini, dan mendorong otoritas daerah untuk menyediakan area ruang terbuka publik. Ruang terbuka publik dapat didefinisikan sebagai taman, ruang terbuka hijau di dalam kota, yang menyediakan beberapa fasilitas di dalam area tersebut. Ruang terbuka publik ini akan menjadi tempat yang penting bagi setiap orang yang tinggal di sekitarnya jika area ruang terbuka publik tersebut dapat menyediakan fasilitas yang dapat digunakan sebagai tempat bersosialisasi, bertemu dengan orang baru (networking), sebagai titik kumpul ataupun untuk aktifitas lainnya. Ruang terbuka publik ini juga dapat menjadi tempat yang menarik bila tempat tersebut menyediakan beberapa fasilitas pendukung bagi berbagai aktifitas baik untuk anak, dewasa maupun orang tua seperti fasilitas olahraga, fasilitas bermain anak, tempat pasif untuk relaksasi dan juga sebagai area konservasi untuk kawasan hijau. Penelitian ini ditujukan untuk menganalisis pola bagaimana orang-orang khususnya pengunjung ruang terbuka publik tersebar di dalam area yang dikaitkan dengan posisi dari fasilitas-fasilitas tersebut. Taman Tabebuya yang berlokasi di Ciganjur Jagakarsa dipilih menjadi studi kasus, karena taman ini merupakan salah satu ruang terbuka publik yang dianggap indah di Jakarta Selatan. Metode penelitian yang digunakan adalah metode kuantitatif dengan memberikan beberapa data yang dikumpulkan khususnya pada hari Sabtu dan Minggu sepanjang hari dengan waktu-waktu tertentu yaitu pagi, siang dan sore hari.
\end{abstract}

Kata kunci : Ruang Terbuka Publik; Tabebuya; Pola Sebaran.

\begin{abstract}
Providing open publik space within city is become one of an issue in metropolitan city, particularly Jakarta. The limited land and area, which should be provided for publik open space is very hard to find. Nowadays, local government is willing to think about this issue, and encourage local authority to provide the area for publik open space. Publik open space could be defined as a parks, green open space within city which provide some facilities within the area. This publik open space will become an important place for everyone who lives within surrounding area, because the area could become a place for socialization, for networking, for meeting point and for other activities. This publik open space will become more exciting place, if the place consists some facilities such as sport activities, playground facilities, passive place for relaxation, and as a conservation area for green area. This research is aimed to analyze the pattern of how people is distributed within area referring to the facilities existed. Taman Tabebuya which is located in Ciganjur Jagakarsa, has been chosen as a case study, because this place has been regarded as one of beautiful garden in South Jakarta. The method of this research is a quantitative method by providing some data which has been collected on Saturday and Sunday, during morning, noon and afternoon.
\end{abstract}

Keywords :Publik Open Space; Tabebuya; Distribution Pattern.

\footnotetext{
${ }^{1}$ Jurusan Arsitektur, Universitas Muhammadiyah Jakarta
} 


\section{PENDAHULUAN}

Kebutuhan akan ruang terbuka publik di dalam suatu kawasan perkotaan setidaknya mencakup 30\% dari seluruh lahan yang ada, namun pada kenyataannya, ruang kota sudah sangat terbatas dalam penyediaan ruang terbuka publik. Ruang terbuka publik di sini tidak hanya ruang terbuka yang berfungsi sebagai wadah kegiatan masyarakat, namun juga meliputi ruang terbuka hijau seperti taman maupun jalur hijau yang berfungsi sebagai area peresapan maupun sumber penghijauan sebagai peredam polusi udara.

Salah satu usaha pemerintah pusat dalam menanggulangi masalah perkotaan yang berkaitan dengan ruang terbuka publik ini adalah dengan mendorong pemerintah daerah khususnya otoritas daerah yang bekerjasama dengan instansi terkait dalam mewujudkan penyediaan ruang terbuka publik. Dengan adanya peraturan daerah yang mewajibkan penyediaan ruang terbuka publik ini, maka otoritas daerah berlomba-lomba dalam menyediakan fasilitas tersebut. Salah satu fungsi dari ruang terbuka publik bagi masyarakat adalah dengan menyediakan fasilitas-fasilitas pendukung kegiatan masyarakat di dalam ruang terbuka publik tersebut sehingga pemanfaatan ruang terbuka tersebut menjadi optimal dan maksimal.

Tulisan ini merupakan hasil penelitian sederhana yang memilih Taman Tabebuya sebagai obyek penelitian dengan pengunjung taman sebagai variable yang digunakan dalam penelitian ini. Hasil dari penelitian adalah dengan melihat pola sebaran pengunjung sehingga dapat dilihat bagaimana fasilitas pendukung dapat menjadi salah satu obyek pasif ataupun aktif yang digunakan pengunjung sebagai salah satu hal penting dan dominan dalam suatu ruang terbuka publik.

\section{METODOLOGI}

Tulisan ini merupakan hasil dari penelitian yang telah dilakukan dengan mengeksplorasi seberapa jauh ruang terbuka publik digunakan secara optimal bagi masyarakat. Dengan menggunakan metode kuantitatif, penelitian ini menggunakan kompilasi data, untuk melihat pola sebaran pengunjuang di dalam Taman Tabebuya dengan melihat trend pada grafik yang disajikan. Penelitian selama dua hari dalam satu minggu dilakukan pada hari Sabtu dan Minggu untuk melihat perbedaannya, hal ini mengingat bahwa hari Sabtu dan Minggu merupakan hari libur anak sekolah dan juga akhir pekan bagi para orang tua yang bekerja. Beberapa waktu yang signifikan dipilih untuk melihat hasil yang signifikan yaitu pagi hari, siang hari dan sore hari. Namun, teori yang ada tetap digunakan dalam proses analisis temuan untuk menghasilkan kesimpulan yang tepat.

\section{HASIL DAN PEMBAHASAN}

\section{A. Apa itu Ruang Terbuka Publik?}

Menurut Hakim (2003), ruang terbuka hijau dapat didefinisikan sebagai ruang yang terbentuk karena kebutuhan akan tempat untuk bertemu, bersosialisasi atau berkomunikasi antar individu. Untuk mengakomodir kebutuhan akan tempat bertemu antar individu, setiap individu akan menciptakan berbagai kegiatan di dalam area ruang terbuka. Mengacu pada kondisi ini, dapat dikatakan bahwa ruang terbuka public adalah ruang yang dapat mengakomodasi kegiatan khusus dari manusia baik secara individu maupun berkelompok. Budihardjo (2009) mengatakan bahwa ruang terbuka public merupakan ruang yang dapat 
direncanakan dan diciptakan untuk tempat bertemu dan untuk kegiatan komunal di dalam ruang terbuka.

Di lain pihak, Carr (1992) menyatakan bahwa ruang terbuka public merupakan tempat dimana terdapat kebersamaan yang terjadi antar individu. Jalan raya, Jalan lingkungan, Jalan setapak, taman dan plaza akan memiliki peran di dalam kegiatan dan kehidupan manusia. Ruang dinamis dapat dikatakan sebagai nilai tambah dari area residensial dengan kegiatan dan kehidupan yang rutin, dapat mengakomodasi berbagai kegiatan, pusat komunikasi dan ruang komunal untuk bermain dan relaksasi. Sementara itu Krier (1979) mendefinisikan ruang terbuka sebagai ruang yang hadir antara bangunan-bangunan yang ada di perkotaan. Krier menitikberatkan ruang terbukan sebagai ruang di dalam perkotaan.

Dari berbagai definisi di atas mengenai ruang terbuka public, dapat disimpulkan bahwa definisi dari ruang terbuka adalah ruang yang terletak di luar bangunan dan dapat digunakan oleh manusia baik secara individu maupun kelompok untuk melakukan kegiatan-kegiatan sehari-hari, seperti berjalankaki, berolahraga, rekreasi, relaksasi, bersosialisasi dan kegiatankegiatan lainnya yang menunjang kehidupan seseorang.

\section{B. Mengapa Manusia Membutuhkan Bersosialisasi?}

Manusia didefinisikan sebagai makhluk social yang tidak dapat hidup sendiri atau secara individual. Setiap individu akan membutuhkan orang lain untuk dapat bertahan hidup dan melakukan kegiatan baik kegiatan secara individu maupun secara berkelompok. Pada dasarnya, manusia merupakan makhluk individu yang merupakan bagian terkecil dari unit kehidupan social dari manusia sebagai makhluk social, yang membentuk kehidupan bermasyarakat. Manusia dapat didefinisikan sebagai kelompok dari beberapa individu. Kemudian secara konkrit, manusia dapat dipisahkan sebagai makhluk individu dan makhluk social yang dapat dijelaskan sebagai berikut:

Manusia sebagai makhluk individu menurut Effendi (2010) dinyatakan sebagai individu yang dapat dijabarkan dari kata "in" dan "divided" yang dapat dimaknai sebagai kesatuan, tidak dapat dipisahkan dan tidak dapat dibagi-bagi. Yang dimaksud di sini adalah bahwa manusia sebagai makhluk individu merupakan satu kesatuan aspek jasmani dan rohani atau fisik dan psikologis yang tidak dapat dipisahkan satu sama lainnya. Sementara itu manusia sebagai makhluk social berasal dari kata latin "socius" yang artinya berkawan atau masyarakat. Sosial dapat dikatakan sebagai kemasyarakatan atau dalam makna sempit adalah mendahulukan kepentingan bersama atau masyarakat. Sehingga dari arti tersebut, manusia sebagai makhluk social dapat dimaknai sebagai makhluk yang selalu hidup bersama dengan manusia lain, yaitu makhluk yang tidak dapat hidup sendiri dan melakukan semua kegiatannya sendiri tanpa adanya keterlibatan orang lain.

Manusia akan selalu membutuhkan orang lain, karena dalam dirinya secara naluri memiliki dorongan untuk berhubungan dan berinteraksi dengan orang lain, hal ini menjadi kebutuhan sehari-hari. Dengan adanya fenomena ini, maka dapat digarisbawahi di sini bahwa manusia akan selalu mencari orang lain yang didasari atas kesamaan diri sesuai dengan kesamaan kepentingan satu sama lainnya. Dalam berkegiatan yang beragam di dalam lingkungan masyarakat, manusia akan selalu membutuhkan orang lain dan membutuhkan wadah untuk melakukan kegiatan tersebut. Wadah berkegiatan inilah yang kemudian dikenal sebagai ruang berinteraksi bagi individu baik secara individu maupun secara berkelompok. 


\section{Temuan dan Hasil}

Penelitian sederhana ini dilakukan di salah satu taman kota di Jakarta Selatan, yaitu tepatnya di Taman Tabebuya, di Jalan Mohammad Kahfi I, Ciganjur, Jagakarsa, Jakarta Selatan. Taman ini merupakan salah satu taman terindah di Jakarta Selatan, hal ini terbukti dengan seringnya taman ini digunakan sebagai lokasi shooting film ataupun sinetron. Taman kota ini dahulunya adalah milik pribadi seseorang yang kemudian diwakafkan untuk kepentingan umum. Pemilik terdahulunya yaitu almarhum dr. Herman Susilo (mantai ketua PMI) bertempat tinggal tepat di sebelah Taman Tabebuya, dengan lokasi rumah berada lebih tinggi dari taman. Setelah pemilik wafat, rumah dibeli oleh salah satu production house, dan inilah salah satu yang menyebabkan Taman Tabebuya ini menjadi lokasi shooting film maupun sinetron. Selain digunakan untuk lokasi shooting, Taman Tabebuya juga sering digunakan untuk lokasi pemotretan.

Penelitian ini bertujuan untuk melihat pola sebaran pengunjung Taman Tabebuya saat menjelang akhir pekan. Saya mengamati dan menghitung jumlah pengunjung selama dua hari yaitu pada hari sabtu (15.10.2016) dan minggu (16.10.2016), dimana pada kedua hari tersebut pengunjung relatif lebih banyak daripada hari biasanya.

Pengamatan dilakukan dengan menentukan 3 waktu yaitu pada:

1. pagi hari : pukul 07.00-10.00

2. siang hari : pukul 12.00-15.00

3. sore hari : pukul 16.00-18.00

Deskripsi tentang bagaimana pola sebaran pengunjung Taman Tabebuya dapat dilihat pada peta berikut ini. Pemetaan pola sebaran pengunjung memperlihatkan di lokasi mana saja, yang terdapat banyak pengunjungnya. Hal ini disebabkan adanya beberapa hal yaitu diantaranya karena adanya fasilitas-fasilitas penunjang di dalam Taman Tabebuya:

1. Titik A: Tepian danau, merupakan tempat favorit kedua setelah taman bermain anak, karena biasanya digunakan untuk piknik, sambil lesehan menggelar tikar dan bersantai menikmati pemandangan danau

2. Titik B: Taman bermain anak, yang dilengkapi dengan fasilitas bermain seperti jungkatjungkit, perosotan, ayunan, bola berputar dan aktifitas pergerakan anak seperti untuk memanjat, bergelanyutan dan lainnya.

3. Titik C: Gazebo, dengan dimensi yang tidak terlalu besar, membuat tempat ini menjadi rebutan, karena beberapa orang menggunakan tempat ini selain untuk duduk-duduk juga untuk bekerja sambil menunggu anak bermain, fasilitas penunjang yang ada di dalam gazebo ini adalah meja sehingga dapat digunakan sebagai alas untuk meletakkan laptop

4. Titik D dan Titik E: Area piknik, area ini memang disediakan untuk piknik keluarga, ada dua area di dalam Taman Tabebuya ini yaitu tepat di depan gazebo dan satunya lagi adalah di seberang taman bermain anak. Dengan adanya bangku dari semen dan beton yang berbentuk melingkar, memberikan kenyamanan bagi pengunjung untuk sekedar dudukduduk atau menikmati santapan makan siang dengan berpiknik. 
5. Titik F: Bangku-bangku, fasilitas ini tersebar di dalam Taman Tabebuya, yang paling banyak berlokasi di dekat area parker, biasanya digunakan oleh pasangan-pasangan muda untuk sekedar duduk-duduk dan bercengkerama.

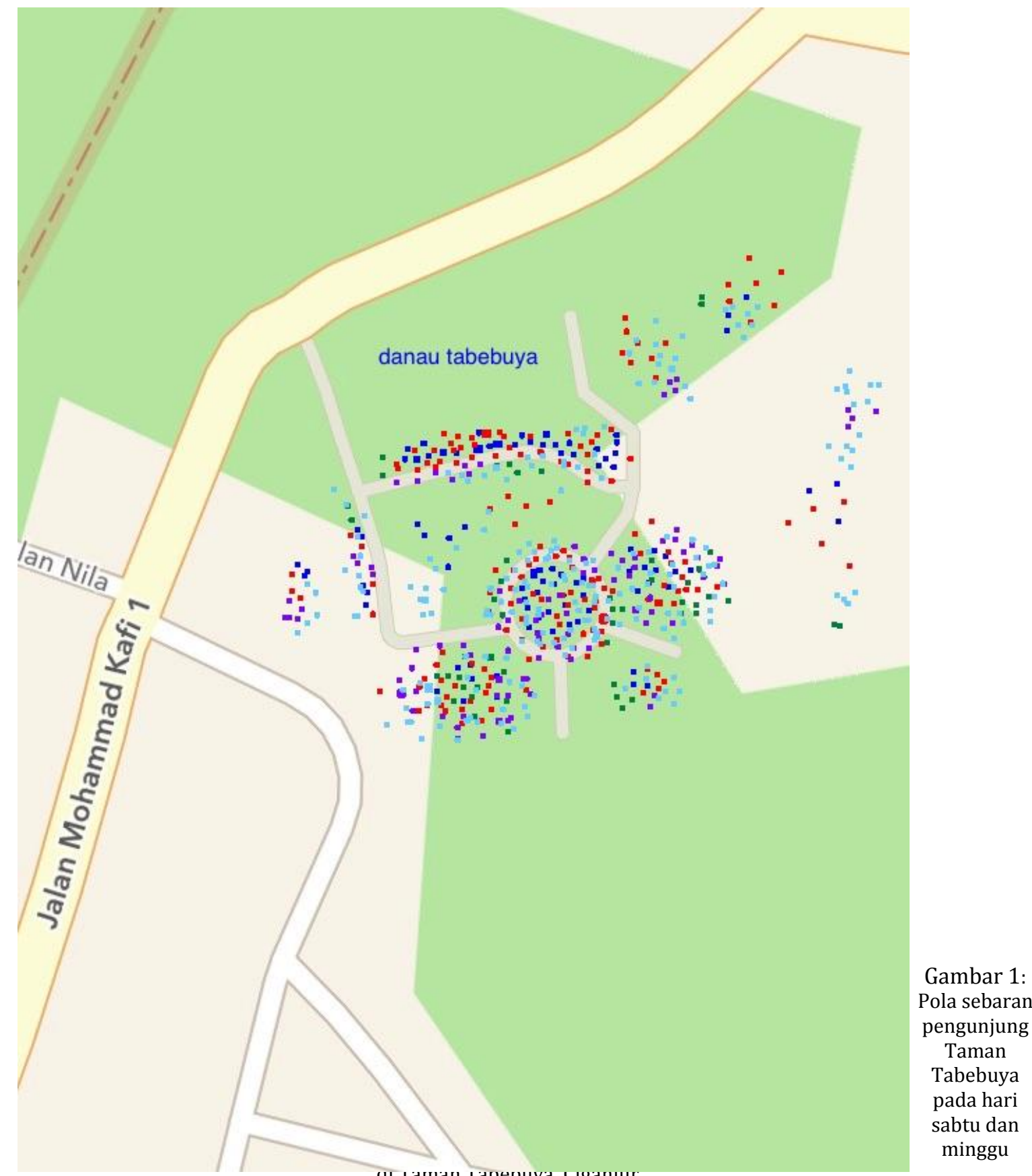

Sumber: Hasil Analisis Peneliti, 2016

Pengunjung di sabtu pagi

Pengunjung di minggu pagi

Pengunjung di sabtu siang
Pengunjung di minggu siang

Pengunjung di sabtu sore

Pengunjung di minggu sore 
Adapun perolehan data pengamatan dapat dilihat pada tabel 1 berikut ini:

Tabel 1: Rekapitulasi data jumlah pengunjung pada hari sabtu dan minggu di Taman Tabebuya, Ciganjur, Jagakarsa

\begin{tabular}{|c|c|c|c|c|c|c|c|}
\hline \multirow[t]{2}{*}{ No } & \multirow[t]{2}{*}{ Titik lokasi } & \multicolumn{2}{|c|}{ Pagi: 07.00-10.00 } & \multicolumn{2}{|c|}{ Siang: 12.00-15.00 } & \multicolumn{2}{|c|}{ Sore: $16.00-18.00$} \\
\hline & & Sabtu & Minggu & Sabtu & Minggu & Sabtu & Minggu \\
\hline 1 & A: Tepi Danau & 21 & 33 & 5 & 9 & 12 & 25 \\
\hline 2 & $\begin{array}{l}\text { B: Taman } \\
\text { bermain anak }\end{array}$ & 46 & 51 & 8 & 12 & 56 & 68 \\
\hline 3 & $\begin{array}{l}\text { C: Gazebo } \\
\text { (tempat } \\
\text { berteduh } \\
\text { beratap) }\end{array}$ & 3 & 5 & 4 & 2 & 6 & 4 \\
\hline 4 & $\begin{array}{l}\text { D: Area piknik } \\
1\end{array}$ & 11 & 12 & 14 & 18 & 25 & 28 \\
\hline 5 & E: Area piknik 2 & 7 & 20 & 12 & 15 & 18 & 22 \\
\hline 6 & $\begin{array}{l}\text { F: Tempat } \\
\text { duduk-duduk }\end{array}$ & 5 & 4 & 2 & 4 & 6 & 10 \\
\hline 7 & Tersebar & 8 & 22 & 4 & 8 & 28 & 36 \\
\hline T0 & AL Pengunjung & 101 & 147 & 49 & 68 & 151 & 193 \\
\hline TO & AL Sabtu & & & 30 & ang & & \\
\hline T0 & AL Minggu & & & 40 & ang & & \\
\hline
\end{tabular}

Sumber: Hasil Analisis Peneliti, 2016

Dari hasil rekapitulasi di atas maka didapatkan grafik pola sebaran pengunjung Taman Tabebuya sebagai berikut:

Grafik 1: Pola Sebaran Pengunjung Taman Tabebuya Hari Sabtu dan Minggu

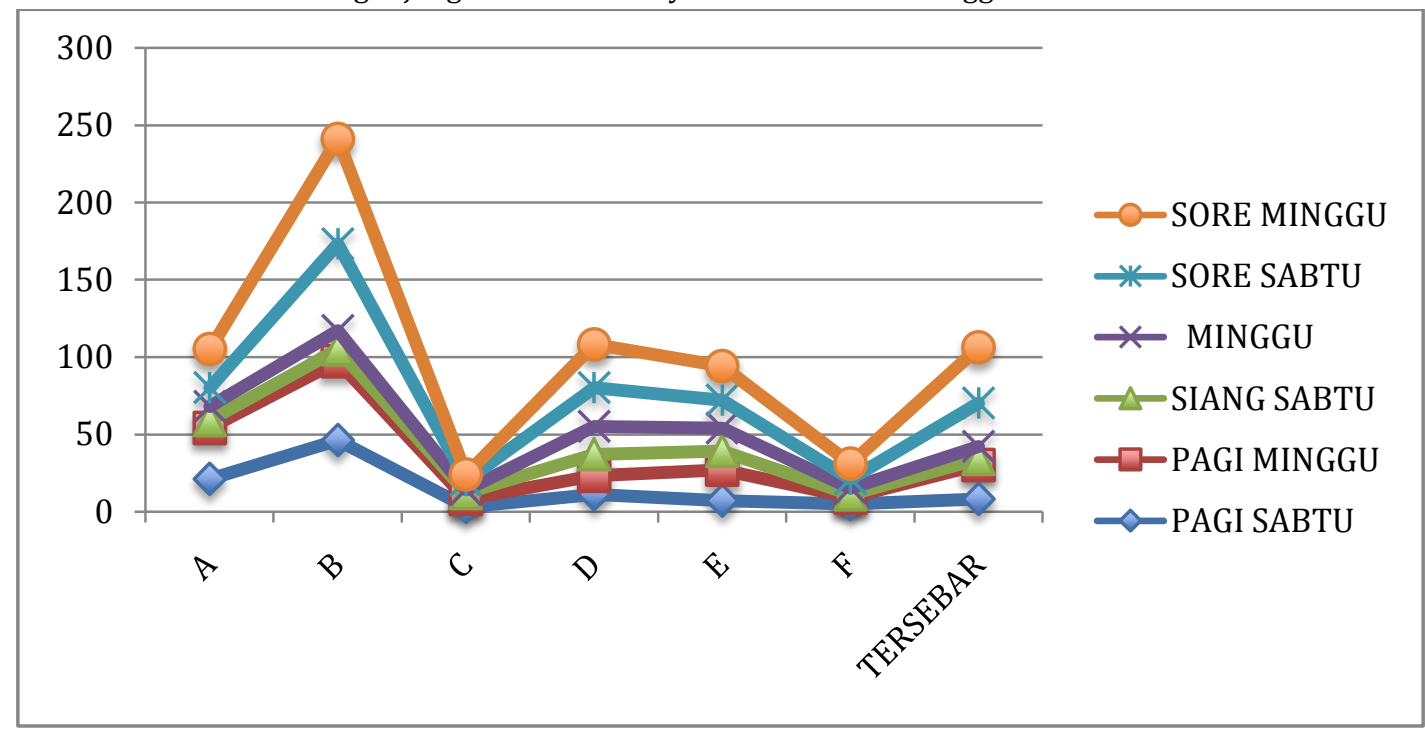

Sumber: Hasil Analisis Peneliti, 2016

Dari grafik 1 terlihat dengan jelas, bahwa jumlah pengunjung tertinggi adalah pada hari sabtu dan minggu pada sore hari. Dan titik kumpul paling banyak terdapat pada titik B, hal ini dikarenakan pada titik B terdapat area bermain anak, dan fasilitas tempat duduk di 
sekeliling area bermain, yang dapat digunakan orang tua untuk menunggu anak bermain. Area gazebo merupakan tempat paling sedikit dikunjungi, hal ini dikarenakan ukuran gazebo yang relatif kecil, yang hanya dapat menampung 2-6 orang, dan jika satu keluarga sudah menempati gazebo tersebut, maka keluarga lain merasa tidak nyaman untuk duduk di gazebo tersebut.

\section{KESIMPULAN}

Dari hasil penelitian dapat ditarik kesimpulan, bahwa pola sebaran pengunjung sebuah taman akan tergantung dari fasilitas pendukung yang terdapat di dalam taman tersebut. Seperti yang telah dipaparkan sebelumnya bahwa sebuah ruang terbuka public akan menjadi penting bagi seseorang, bila tempat tersebut memiliki beberapa fasilitas pendukung yang dapat mengakomodasi kebutuhan orang dalam beraktifitas. Hasil penelitian menunjukkan bahwa sebaran terbanyak dari pengunjung Taman Tabebuya adalah pada area yang memiliki area bermain anak dengan fasilitas pendukung kegiatan bermain anak-anak di mana di dalamnya juga terdapat fasilitas tempat duduk yang dapat memenuhi kebutuhan orang tua saat menunggu anakanak mereka bermain.

\section{DAFTAR REFERENSI}

Krier, Rob. (1979). Urban Space. Academic Edition. London.

Carr, Stephen. (1992). Public Space. Cambridge University Press. England. 1992.

Hakim, Rustam. (2004). Arsitektur Lansekap,Manusia, Alam dan Lingkungan. Penerbit Bina Aksara Jakarta.

Budihardjo, Eko. (2009). Penataan Ruang dan Pembangunan Kota. Bandung: Alumni.

Effendi, S. (2010). Keterkaitan Ruang Terbuka Hijau dengan Urban Heat Island Wilayah Jabotabek. Institut Pertanian Bogor. 